DOI: https://doi.org/10.24127/ajpm.v10i2.3474

\title{
HUBUNGAN ANTARA KEMAMPUAN UNPACKING DAN KONSTRUKSI NEGASI PERNYATAAN MATEMATIKA
}

\author{
Kimura Patar Tamba ${ }^{1^{*}}$ \\ 1* Pendidikan Matematika, Universitas Pelita Harapan, Tangerang, Indonesia. \\ *Corresponding author \\ E-mail: $\quad$ kimura.tamba@uph.edu ${ }^{1 *}$
}

Received 11 January 2021; Received in revised form 18 June 2021; Accepted 29 June 2021

\begin{abstract}
Abstrak
Kemampuan unpacking dan konstruksi negasi dari pernyataan matematika merupakan hal penting dalam pemahaman mengenai pernyataan matematika, pembuktian bahkan memahami konsep matematika dibaliknya. Kemampuan unpacking diasumsikan berhubungan dengan kemampuan konstruksi negasi. Penelitian ini bertujuan untuk menguji hubungan antara kemampuan unpacking dan konstruksi negasi dari pernyataan matematika. Penelitian ini merupakan penelitian kuantitatif dengan metode survey terhadap 35 calon guru matematika, yaitu 28 perempuan dan 7 laki-laki. Calon guru matematika ini sedang mengikuti perkuliahan logika dan teori himpunan. Penelitian ini menggunakan tes yang memuat delapan pernyataan yang diminta untuk di-unpacking dan dikonstruksi negasinya. Data hasil tes dianalisis secara kuantitatif menggunakan statistik deskriptif dan inferensial. Statistik deskriptif menggunakan rata-rata, maksimum, minimum dan standar deviasi. Statistik inferensial menggunakan korelasi pearson's product-moment. Hasil penelitian menunjukkan tingkat kemampuan unpacking calon guru matematika berada pada kategori sedang dan kemampuan konstruksi negasi pada kategori sedang. Hasil penelitian juga menunjukkan tidak adanya hubungan signifikan antara kemampuan unpacking dengan kemampuan konstruksi negasi pernyataan matematika. Temuan penelitian mengimplikasikan pentingnya mengembangkan proses dimana calon guru matematika didorong untuk melakukan evaluasi mengenai pernyataan matematika.
\end{abstract}

Kata kunci: Logika; negasi; pernyataan matematika; unpacking.

\begin{abstract}
The ability to unpack and construct the negation of mathematical statements is important in understanding mathematical statements, proving and even understanding the mathematical concepts behind them. The unpacking ability is assumed to be related to the negation construction capability. This study aims to examine the relationship between unpacking abilities and the negation construction of mathematical statements. This research is a quantitative study with a survey method of 35 pre-service mathematics teachers. This study uses a test that contains eight statements which are asked to be unpacked and constructed for negation. Data were analyzed quantitatively using descriptive and inferential statistics. Descriptive statistics use mean, maximum, minimum and standard deviation. Inferential statistics use product-moment correlation. The results showed the level of unpacking ability of prospective mathematics teachers was in the medium category and the negation construction ability was in the medium category. The results also showed that there was no significant relationship between unpacking ability and the negation construction ability of mathematical statements. The research findings imply the importance of developing a process by which pre-service mathematics teachers are encouraged to evaluate mathematics statements.
\end{abstract}

Keywords: Logic; mathematical statement; negation; unpacking.

This is an open access article under the Creative Commons Attribution 4.0 International License

\section{PENDAHULUAN}

Buku teks matematika sering menuliskan pernyataan matematika secara implisit. Misalnya, buku teks sering tidak menuliskan kuantifikasi (kuantor) dalam menulis definisi ataupun teorema, meskipun kuantor masih melekat pada konsep matematika tersebut (Morgan, 2020; Stewart, 2012) Penyajian konsep matematika (dalam 
bentuk definisi ataupun teorema) dengan pernyataan yang tidak memiliki struktur logika formal yang eksplisit sering melahirkan ambiguitas (Morgan, 2020; Ngansop, 2018; Shipman, 2016).

Pernyataan yang tidak memiliki struktur logika formal yang eksplisit perlu di-unpacking sehingga ambiguitas dalam memaknainya dapat dihindarkan. Untuk itu calon guru matematika harus memiliki kemampuan melakukan unpacking pernyataan matematika. Unpacking pernyataan matematika artinya kemampuan menulis ulang pernyataan matematika informal menjadi pernyataan formal (Morgan, 2020; Ngansop, 2018; Uygur-Kabael, 2017). Contoh unpacking yaitu mengubah pernyataan informal seperti "fungsi kontinu ketika ia terdiferensialisasi" menjadi pernyataan formal "untuk setiap fungsi $f$, jika $f$ terdiferensialkan maka $f$ kontinu". Pernyataan formal hasil unpacking ini memiliki stuktur yang jelas dan eksplisit yaitu kuantor dinyatakan secara eksplisit (untuk setiap), predikat juga dituliskan secara eksplisit dengan simbolik (fungsi $f$ ) dan struktur penghubungannya terlihat jelas (jika...maka...). Dengan melakukan unpacking struktur dan makna dari pernyataan lebih mudah dipahami. Hal ini memiliki implikasi pada konstruksi negasi dari pertanyaan tersebut.

Meskipun belum menjadi topik umum, beberapa penelitian mengenai unpacking telah dilakukan (misalnya, Morgan, 2020; Ngansop, 2018; Shipman, 2016; Uygur-Kabael, 2017). Penelitian dari Morgan (2020) dan Uygur-Kabael (2017) menunjukkan mahasiswa kesulitan memahami dan menginterpretasi pernyataan berkuantor yang strukturnya implisit. Mahasiswa cenderung sulit melakukan unpacking atas pernyataan berkuantor yang strukturnya implisit. Temuan yang sama juga diungakpak oleh penelitian Ngansop (2018) bahwa kemampuan unpacking (mengetahui struktur logis) dari sebuah pernyataan memungkinkan mahasiswa untuk mengklarifikasi ambiguitas yang diakibatkan oleh bahasa. Bahkan penelitian dari Shipman (2016) kurangnya kemampuan unpacking menimbulkan kesulitan dalam mengkonstruksi bukti.

Berbagai penelitian tersebut mengungkapkan mahasiswa kesulitan dalam melakukan unpacking pernyataan matematika. Namun, penelitian tersebut belum menganalisis mengenai hubungan kemampuan unpacking dengan konstruksi negasi pernyataan matematika secara kuantitatif dan spesifik (Morgan, 2020; Ngansop, 2018; Shipman, 2016; Uygur-Kabael, 2017). Dengan demikian, penting melihat hubungan kemampuan unpacking dan kemampuan mengkonstruksi negasi penting dilakukan.

Kemampuan mengkonstruksi negasi penting karena agar dapat mengevaluasi dan menentukan nilai kebenaran serta mengembangkan bukti logis dari suatu pernyataan, mahasiswa harus memahami negasinya (Morgan, 2020). Sementara itu, penelitian mengenai topik negasi pernyataan matematika belum juga melihat hubungan kemampuan mengkonstruksi negasi dengan kemampuan unpacking (misalnya, Macbeth et al., 2013; Morgan, 2020; Nurjanah et al., 2019). Dengan demikian, penting dilakukan suatu studi mengenai hubungan kemampuan mengkonstruksi negasi dengan kemampuan unpacing. Oleh karena itu, penelitian ini bertujuan untuk menguji dan menganalisis hubungan antara kemampuan unpacking pernyataan matematika dan kemampuan mengkonstruksi negasi dari pernyatan 
matematika. Analisis hubungan ini dilihat dalam dua hal yaitu analisis korelasi (asosiasi) dan analisis pengaruh. Secara detail, penelitian ini akan menguji dan menganalisis: (1) deksripsi kemampuan unpacking pernyataan matematika dan kemampuan mengkonstruksi negasi pernyataan matematika; (2) hubungan antara kemampuan unpacking pernyataan matematika dengan kemampuan mengkonstruksi negasi pernyataan matematika.

\section{METODE PENELITIAN}

Penelitian ini adalah penelitian kuantitatif dengan menggunakan metode survei dan desain crosssectional. Desain ini dipilih karena kebutuhan untuk memperoleh data dari beberapa variabel secara bersamaan (Cohen et al., 2018). Penelitian ini dimulai dengan menganalisis indikator kemampuan unpacking dan konstruksi negasi pada mata kuliah logika dan teori himpunan. Lalu, instrumen disusun dan dilakukan validasi. Kemudian survei dilakukan dengan menggunakan kedua tes secara bersamaan.

Sebanyak 35 orang calon guru matematika (28 perempuan dan 7 lakilaki) menjadi partisipan dalam penelitian ini. Penelitian ini dilaksanakan di Universitas Pelita Harapan, Tangerang, Indonesia. Pemilihan partisipan dilakukan secara purposive sampling, karena penelitian bertujuan menguji hubungan kemampuan unpacking dan mengkonstruksi negasi dari pernyataan matematika. Oleh karena itu partisipan yang dipilih adalah calon guru yang telah memiliki pemahaman mengenai unpacking dan negasi pernyataan matematika. Partisipan telah menyelesaikan mata kuliah logika dan teori himpunan. Partisipan juga telah lulus pada mata kuliah Kalkulus I. Pemilihan ini dilakukan karena pernyataan matematika yang akan digunakan dalam penelitian ini adalah teorema-teorema dalam Kalkulus I.

Survei dilakukan untuk mengumpulkan data kemampuan unpacking dan kemampuan mengkonstruksi negasi pernyataan matematika. Instrumen yang digunakan adalah tes yang terdiri dari dua permasalahan. Permasalahan pertama bertujuan menguji kemampuan unpacking pernyataan matematika. Pada permasalahan pertama ini, calon guru matematika diminta untuk melakukan unpacking 8 (delapan) pernyataan matematika. Pernyataan yang digunakan adalah teorema-teorema mengenai fungsi (kontiniutas, turunan) dari kalkulus I. Pernyataan ini diambil dari buku teks Kalkulus I. Permasalahan kedua adalah mengkonstruksi negasi dari 8 (delapan) pernyataan matematika yang digunakan pada permasalahan pertama. Artinya permasalahan pertama dan kedua menggunakan pernyataan matematika yang sama. Kedelapan pernyataan tersebut dapat dilihat pada Tabel 1.

Tabel 1. Pernyataan yang digunakan dalam tes

\begin{tabular}{ll}
\hline No & Pernyataan \\
\hline 1. Untuk $a<b$ terdapat $c$ sehingga $f(c)=y$ bilamana $f(a)<y$ dan $y<f(b)$ \\
2. Terdapat sebuah fungsi $g$ sedemikian sehingga $g^{\prime}=y$ bilamana $f$ kontinu untuk \\
setiap $x$ \\
3. Jika $f$ terdefinisi pada $a$, maka $_{x \rightarrow a} f(x)$ ada, akibatnya $f$ kontinu pada $a$
\end{tabular}




\begin{tabular}{ll}
\hline No & \multicolumn{1}{c}{ Pernyataan } \\
\hline 4. & Fungsi $f$ naik pada interval $I$ artinya bahwa untuk setiap bilangan $x_{1}$ dan $x_{2}$ \\
& dalam $I$, jika $x_{1}<x_{2}$ maka $f\left(x_{1}\right)<f\left(x_{2}\right)$ \\
5. Jika $\lim _{x \rightarrow c} f(x)$ adalah bernilai positif, maka terdapat interval terbuka \\
sedemikian sehingga $f(x)>0$ untuk setiap $x \neq c$ dalam interval \\
6. Jika $f^{\prime}(x)=g^{\prime}(x)$ untuk setiap $x$ dalam interval $I$ maka $f$ dan $g$ berbeda oleh \\
sebuah konstanta $k$ sedemikian sehingga $f(x)-g(x)=k$, untuk semua $x$ dalam $I$ \\
7. Jika $f(c)$ tidak merupakan maksimum lokal atau minimum lokal dari $f$ maka \\
antara $f^{\prime}(c)=0$ atau $f^{\prime}(c)$ tidak terdefinisi \\
8. Jika $g$ kontinu pada $c$ dan $f$ kontinu pada $g(c)$ maka $f o g$ kontinu pada $c$
\end{tabular}

Validasi tes dilakukan dengan menggunakan korelasi Pearson's product moment. Nilai koefisien korelasi item soal tes kemampuan unpacking dan kemampuan konstruksi negasi berada pada rentang 0,374 sampai 0.796 dan signifikan pada $\alpha=0,05$. Ini menunjukkan item tes valid. Uji reliabilitas dilakukan dengan menggunakan Cronbach-Alpha. Nilai koefisien $r$ Cronbach-Alpha sebesar 0,350 untuk tes kemampuan unpacking dan 0,586 untuk tes kemampuan konstruksi negasi. Nilai ini lebih besar dari nilai $r$-tabel $=0,33$. Ini menunjukkan instrument tes memiliki reliabilitas yang dapat diterima, meskipun tidak sangat kuat.

Analisis data dilakukan dengan tiga tahap. Tahap pertama adalah memberikan skor pada jawaban calon guru matematika untuk tes yang diberikan. Pedoman penskroan untuk permasalahan pertama dan kedua dilakukan secara berbeda. Pada permasalahan pertama, penskoran dilakukan dengan menggunakan kerangka kalkulus predikat. Dalam kalkulus predikat, bahasa formal terdiri dari huruf untuk variabel dan predikat, simbol untuk konektor logis, dan kuantor eksistensial dan universal (Morgan, 2020; Ngansop, 2018). Oleh karena itu, skor 1 akan diberikan jika masing-masing unsur bahasa formal matematika muncul dalam jawaban calon guru matematika. Dengan demikian total skor yang dapat diperoleh untuk masing-masing pernyataan adalah 3. Pada permasalahan kedua, penskoran dilakukan dengan skala 0-2. Skor 0 diberikan jika tidak ada jawaban, skor 1 diberikan jika negasi yang diberikan tidak tepat dan 2 jika negasi yang diberikan tepat.

Tahap kedua, data kemampuan unpacking dan kemampuan konstruksi negasi pernyataan matematika yang diperoleh dari penskoran dianalisis secara statistik deskriptif. Statistik deskriptif meliputi nilai mean, maksimum, minimum dan standar deviasi. Untuk kemampuan unpacking, analisis statistik deskriptif juga akan dilakukan berdasarkan komponen kalkulus predikat. Selain itu data kemampuan unpacking dan kemampuan konstruksi negasi akan dikategorikan dalam tinggi, sedang dan rendah. Kategorisasi ini menggunakan teknik statistik hipotetik (Sugiyono, 2012) seperti terlihat pada Tabel 2.

Tahap ketiga, analisis dilakukan dengan menghitung nilai korelasi pearson's moment product dan analisis regresi antar kemampuan unpacking dan kemampuan konstruksi negasi. Analisis dilakukan dengan menggunakan batuan software SPSS 20.0. 
DOI: https://doi.org/10.24127/ajpm.v10i2.3474

Tabel 2. Kategorisasi skor

\begin{tabular}{ccc}
\hline Kategori & Kemampuan Unpacking & Kemampuan Konstruksi Negasi \\
\hline Tinggi & $X>16,00$ & $X>10,67$ \\
Sedang & $8,00<X \leq 16,00$ & $5,33<X \leq 10,67$ \\
Rendah & $X \leq 8,00$ & $X \leq 5,33$ \\
\hline
\end{tabular}

\section{HASIL DAN PEMBAHASAN}

Hasil penelitian akan dipaparkan dalam dua bagian yaitu pertama mengenai analisis deskriptif kemampuan unpacking dan kemampuan konstruksi negasi pernyataan matematika. Bagian kedua, memaparkan hasil analisis korelasi antar kemampuan unpacking dan kemampuan konstruksi negasi pernyataan matematika. Bagian kedua juga mengungkapkan hasil analisis regresi untuk melihat hubungan fungsi interaktif antar kemampuan unpacking dan kemampuan konstruksi negasi pernyataan matematika. Data kemampuan unpacking dan kemampuan konstruksi negasi dilakukan dengan menggunakan kerangka yang telah dipaparkan di atas. Tabel 3 adalah contoh penskoran atas tes yang diberikan.

Tabel 3. Contoh peskoran yang dilakukan pada jawaban calon guru matematika

\begin{tabular}{|c|c|c|c|c|}
\hline No & Soal & $\begin{array}{l}\text { Contoh jawaban calon guru } \\
\text { matematika }\end{array}$ & Skor & Deskripsi pemberian skor \\
\hline $1 \mathrm{a}$ & $\begin{array}{l}\text { Untuk } a<b \text { terdapat } c \\
\text { sehingga } f(c)=y \\
\text { bilamana } f(a)<y \text { dan } \\
y<f(b)\end{array}$ & $\begin{array}{l}\forall a, b \in R, \exists c \in R, \quad f \text { fungsi } \\
\text { pada R, } a<b, \quad f(a)<y< \\
f(b) \rightarrow f(c)=y \\
\text { (Partisipan No 8) }\end{array}$ & 3 & $\begin{array}{l}\text { Pada jawaban ini, predikat, } \\
\text { kuantor dan konektor logika } \\
\text { dituliskan secara eksplisit } \\
\text { dan benar }\end{array}$ \\
\hline $1 b$ & $\begin{array}{l}\text { Terdapat sebuah fungsi } g \\
\text { sedemikian } \\
g^{\prime}=y \text { bilamana } f \text { kontinu } \\
\text { untuk setiap } x\end{array}$ & $\begin{array}{l}\left\{\exists g(x) \ni g^{\prime}=y\right\} \leftrightarrow \\
\left\{\exists\left(\lim _{x \rightarrow a} f(x)=\right.\right. \\
f(a)), \forall a \in R\} \\
\text { (Partisipan No 6) }\end{array}$ & 1 & $\begin{array}{l}\text { Konektor logika dan kuantor } \\
\text { yang digunakan tidak tepat, } \\
\text { sementara predikat dituliskan } \\
\text { secara eksplisit }\end{array}$ \\
\hline $2 \mathrm{c}$ & $\begin{array}{l}\text { Jika } f \text { terdefenisi pada } a \text {, } \\
\text { maka } \lim _{x \rightarrow a} f(x) \text { ada, } \\
\text { akibatnya } f \text { kontinu pada } a\end{array}$ & $\begin{array}{l}f \text { terdefinisi pada } C \rightarrow \\
\lim _{x \rightarrow a} f(x) \wedge f \text { tidak kontinu } \\
\text { pada } a \\
(\text { Partisipan No 28) }\end{array}$ & 1 & Negasi tidak tepat \\
\hline
\end{tabular}

Pertama, hasil analisis deskriptif kemampuan unpacking dan kemampuan konstruksi negasi pernyataan matematika terlihat pada Tabel 4. Ratarata skor kemampuan unpacking pernyataan matematika sebesar 17,11 . Dari Tabel 3, skor maksimum yang diperoleh adalah 23, dengan skor total yang dapat diperolah adalah skor 24. Artinya tidak ada calon guru matematika yang mampu mengubah pernyataan matematika informal menjadi pernyataan formal untuk semua pernyataan. Jika dilihat berdasarkan komponen unpacking, rata-rata kemam- puan menulis kuantor secara eksplisit sebesar 5,6. Sementara rata-rata kemampuan menulis konektor logika secara eksplisit dan benar sebesar 5,14. Kemampuan menulis predikat secara eksplisit dan tepat sebesar 6,37. Ratarata skor kemampuan konstruksi negasi pernyataan matematika sebesar 8,20. Nilai ini menunjukkan kemampuan konstruksi negasi calon guru matematika berada pada kategori sedang. Skor maksimum sebesar 11,00 (dari skor total 16) artinya tidak ada calon guru matematika yang dapat mengkonstruksi negasi dengan tepat 
DOI: https://doi.org/10.24127/ajpm.v10i2.3474

dari semua pernyataan matematika. Dengan demikian, Tabel 4 bermakna kemampuan unpacking calon guru matematika dan kemampuan mengkonstruksi negasi berada pada kategori sedang.

Tabel 4. Deskripsi kemampuan unpacking dan konstruksi negasi pernyataan matematika

\begin{tabular}{lcccc}
\hline & Min. & Max. & Mean & Std.Dev. \\
\hline $\begin{array}{l}\text { Kemampuan unpacking } \\
\begin{array}{l}\text { Kemampuan menulis kuantor secara eksplisit dan } \\
\text { tepat }\end{array}\end{array}$ & 1,00 & 23,00 & 17,11 & 0,51 \\
$\begin{array}{l}\text { Kemampuan menulis konektor logika secara } \\
\text { eksplisit dan tepat }\end{array}$ & 2,00 & 8,00 & 5,60 & 1,88 \\
$\begin{array}{l}\text { Kemampuan menulis predikat secara eksplisit } \\
\text { dan tepat }\end{array}$ & 0,00 & 8,00 & 6,37 & 1,52 \\
Kemampuan mengkonstruksi negasi & 8,00 & 11,00 & 8,20 & 0,63 \\
\hline
\end{tabular}

Berdasarkan rata-rata, kategori kemampuan unpacking berada pada kategori sedang (Tabel 5). Sementara kategori kemampuan mengkonstruksi negasi pada kategori sedang. Jika dilihat berdasarkan skor individu, sebagian besar $(60 \%)$ calon guru matematika memiliki kemampuan unpacking pada kategori sedang. Kategori sedang artinya tidak semua pernyataan matematika dapat di-unpacking oleh calon guru matematika. Begitu juga dalam hal kemampuan konstruksi negasi, semua (100\%) calon guru matematika pada kategori sedang. Sama seperti kemampuan unpacking, kategori sedang di sini artinya, tidak semua pernyataan dapat dikonstruksi negasinya oleh calon guru matematika. Tabel 5 menunjukkan bahwa sebagian besar calon guru matematika berada pada kategori sedang dalam kemampuan unpacking dan mengkonstruksi.

Tabel 5. Kategori kemampuan unpacking dan mengkonstruksi negasi

\begin{tabular}{lccc}
\hline \multirow{2}{*}{ Kemampuan } & \multicolumn{3}{c}{ Kategori } \\
\cline { 2 - 4 } & Rendah & Sedang & Tinggi \\
\hline Unpacking & 0 & $60 \%$ & $40 \%$ \\
$\begin{array}{l}\text { Mengkonstruksi } \\
\text { negasi }\end{array}$ & 0 & $100 \%$ & 0 \\
\hline
\end{tabular}

Kedua, hasil analisis korelasi antar kemampuan unpacking dan konstruksi negasi pernyataan matematika ditunjukkan pada Tabel 6 . Sebagaimana ditunjukkan pada Tabel 6 , korelasi antara kemampuan unpacking dan konstruksi negasi pernyataan matematika benilai negatif (-0.039) dan tidak signifikan. Artinya tidak terdapat hubungan antara kemampuan unpacking pernyataan matematika dengan kemampuan mengkonstruksi negasinya. Jika dilihat berdasarkan komponen kemampuan unpacking pernyataan matematika juga tidak terdapat korelasi positif dan signifikan kemampuan menulis kuantor secara eksplisit dan tepat dengan kemampuan mengkonstruksi negasi. Bahkan nilai korelasi keduanya negatif (-0.223). Sementara korelasi antar kemampuan menulis konektor logis secara eksplisit dan tepat dengan kemampuan mengkonstruksi negasi juga tidak signifikan. Begitu juga korelasi kemampuan menulis predikat secara eksplisit dan tepat dengan kemampuan mengkonstruksi negasi bernilai positif dan tetapi tidak signifikan. 
DOI: https://doi.org/10.24127/ajpm.v10i2.3474

Tabel 6. Matrik korelasi bivariat antar kemampuan unpacking dengan kemampuan konstruksi negasi

\begin{tabular}{|c|c|c|c|c|c|}
\hline & KU & KU-K & KU-KL & KU-P & KN \\
\hline Kemampuan unpacking (KU) & 1 & $0.772 * *$ & $0.374 *$ & $0.796 * *$ & -0.039 \\
\hline $\begin{array}{l}\text { Kemampuan menulis kuantor secara } \\
\text { eksplisit dan tepat }(\mathrm{KU}-\mathrm{K})\end{array}$ & & 1 & -0.068 & $0.544 * *$ & -0.223 \\
\hline $\begin{array}{l}\text { Kemampuan menulis konektor logis } \\
\text { secara eksplisit dan tepat (KU-KL) }\end{array}$ & & & 1 & -0.080 & 0.012 \\
\hline $\begin{array}{l}\text { Kemampuan menulis predikat secara } \\
\text { eksplisit dan tepat (KU-P) }\end{array}$ & & & & 1 & 0.119 \\
\hline Kemampuan mengkonstruksi negasi (KN) & & & & & 1 \\
\hline
\end{tabular}

**Korelasi signifikan pada level 0,$01 ; *$ Korelasi signifikan pada level 0,05

Berdasarkan hasil analisis di atas, ada dua temuan yang menjawab pertanyaan penelitian. Pertama, kemampuan calon guru matematika dalam unpacking pernyataan matematika berada pada kategori sedang. Artinya tidak semua pernyataan matematika dapat di-unpacking oleh calon guru matematika. Hasil ini sesuai dengan penelitian sebelumnya (Morgan, 2020; Uygur-Kabael, 2017) bahwa mahasiswa kesulitan dalam melakukan unpacking. Kemampuan calon guru matematika dalam mengkonstruksi negasi pernyataan berada pada kategori sedang. Artinya tidak semua pernyataan matematika dapat dikonstruksi negasi oleh calon guru matematika. Hasil penelitian ini sejajar dengan penelitian sebelumnya yang menunjukkan mahasiswa masih kesulitan dalam mengkonstruksi negasi dari suatu pernyataan (Dawkins \& Cook, 2017; Macbeth et al., 2013; Morgan, 2020; Nurjanah et al., 2019).

Kedua, penelitian ini menunjukkan tidak adanya hubungan signifikan antara kemampuan unpacking dan kemampuan mengkonstruksi negasi dari pernyataan matematika. Artinya, meskipun calon guru matematika mampu melakukan unpacking pernyataan matematika dari pernyataan informal menjadi pernyataan formal, tidak menjamin mereka dapat melakukan konstruksi negasinya. Temuan ini berbeda dengan hasil penelitian sebelumnya. Penelitian sebelumnya menunjukkan adanya hubungan antara kemampuan unpacking dengan kemampuan menyusun negasi (Morgan, 2020; Ngansop, 2018). Namun penelitian sebelum menguji hubungan secara kualitatif. Berbeda dengan hasil pada penelitian ini, secara kuantitatif (analisis data secara statistik inferensial) tidak terdapat hubungan yang signifikan. Faktor yang mungkin menyebabkan tidak adanya hubungan signifikan antara kemampuan unpacking dengan kemampuan mengkonstruksi negasi pemaknaan calon guru matematika mengenai penghubung logis dan predikat tidak selalu konsisten atau berubah-ubah. Hal ini diungkapkan oleh penelitian sebelumnya bahwa makna kata penghubung bagi siswa sering berubah dari waktu ke waktu dan dari tugas ke tugas (Dawkins, 2017; Dawkins \& Cook, 2017). Ketidakmapanan makna kata penghubung logis ini menyebabkan meskipun mampu mengubah struktur pernyataan informal ke formal, tetapi calon guru matematika tidak memahami makna dari struktur tersebut. Perubahan yang terjadi hanya pergantian kata menjadi simbol. Misalnya pada soal 2c, 
kata "akibatnya" dipahami oleh calon guru sebagai bentuk logika implikasi, tetapi mereka tidak memahami makna implikasi itu sendiri.

Faktor lain yang mungkin menjadi menyebab tidak signifikannya korelasi antara kemampuan unpacking dengan kemampuan mengkonstruksi negasi adalah proses penalaran dibalik negasi yang tidak sederhana. Konstruksi negasi dari suatu pernyataan dengan tidak hanya sekadar menambahkan kata "tidak" pada predikat, lebih rumit dari cara normatif yang disarankan matematikawan (Dawkins, 2017). Hal ini juga terjadi pada penelitian ini, calon guru matematika kesulitan untuk mengkonstruksi negasi pernyataan dalam bentuk yang eksplisit, yakni tidak sekadar menambahkan kata tidak pada predikat. Dengan kata lain proses konstruksi negasi bukanlah proses yang sederhana atau dangkal. Temuan menunjukkan tidak signifikannya korelasi antara kemampuan unpacking dengan konstruksi negasi dapat disebabkan pemahaman mengenai negasi. Pemahaman prosedural yang hanya menggunakan aturan (yang mungkin hanya tepat pada konteks tertentu) dapat mengakibatkan ketidakmampuan mengkonstruksi negasi meskipun mampu mengubah pernyataan dalam bentuk formal (Morgan, 2020; UygurKabael, 2017). Selain itu, proses yang dangkal (shallow processing) adalah faktor yang menyebabkan calon guru tidak dapat menghubungkan hasil unpacking dengan proses mengkonstruksi negasi (Macbeth et al., 2013). Hal ini menimbulkan meskipun calon guru mampu melakukan unpacking, namun karena adanya shallow processing membuat mereka tidak mampu melakukan proses deduktif (menghubungkan informasi yang lalu dengan informasi baru).
Berdasarkan temuan dan diskusi di atas, penelitian ini berkontribusi pada khasanah pengetahuan dan penelitian mengenai unpacking dan konstruksi pernyataan matematika. Pertama, penelitian ini memberikan pemahaman yang lebih dalam mengenai relasi antara kemampuan unpacking dan kemampuan konstruksi negasi pernyataan matematika. Penelitian ini menunjukkan bahwa kemampuan unpacking yang hanya sekadar membuat eksplisit komponen pernyataan matematika (predikat, penghubung logis dan kuantor) tanpa pemahaman mengenai kuantor tersebut tidak akan membantu calon guru matematika dalam mengkonstruksi negasi. Hal ini memberikan klarifikasi pada temuan penelitian sebelumnya mengenai unpacking dan hubungannya dengan negasi (Morgan, 2020) bahwa kemampuan unpacking tidak bisa dilihat hanya sekadar prosedural mengubah pernyataan informal ke pernyataan informal. Sebaliknya, unpacking harus dilihat juga sebagai proses evaluasi pernyataan matematika. Sebagaimana yang dilakukan oleh penelitian sebelumnya dalam topik kuantor, unpacking pernyataan berkuantor haruslah suatu bentuk evaluasi pada pernyataan tersebut (Levenson et al., 2012; Tabach et al., 2012; Tamba, 2020). Kedua, hasil penelitian ini memberikan konstribusi metodologis dalam memberikan gambaran hubungan antara kemampuan unpacking dengan kemampuan konstruksi negasi. Berbeda dengan penelitian sebelumnya yang secara kualitatif (Morgan, 2020), penelitian ini memberikan gambaran hubungan secara kuantitatif. Implikasi hasil penelitian ini pada pembelajaran logika adalah dalam mengembangkan kemampuan unpacking harus mendorong pemahaman konseptual, 
tidak hanya prosedural, dalam mengubah pernyataan matematika ke dalam bentuk struktur logika yang eksplisit.

Meskipun demikian, penelitian ini memiliki keterbatasan. Pertama, penggunakan metodologi kuantitatif hanya menggambarkan hubungan antar kemampuan unpacking dengan kemampuan mengkonstruksi negasi. Penalaran dibalik fenomena-fenomena dari temuan tidak dapat dieksplorasi dengan temuan ini. Kedua, kerangka dalam mengevaluasi dan memberikan skor pada proses konstruksi negasi hanya terbatas pada benar-salah. Penelitian ini belum memberikan gambaran mengenai proses berpikir dibalik konstruksi negasi yang dilakukan oleh calon guru matematika. Padahal berbagai penelitian sebelumnya mengungkapkan bentuk-bentuk pemahaman yang berbeda mengenai negasi (Dawkins \& Roh, 2016; Macbeth et al., 2013; Morgan, 2020).

\section{KESIMPULAN DAN SARAN}

Berdasarkan dari hasil penelitian dapat disimpulkan tiga hal. Pertama, kemampuan unpacking calon guru matematika berada pada kategori sedang. Kedua, kemampuan konstruksi negasi pernyataan matematika calon guru matematika berada pada kategori sedang. Ketiga, tidak terdapat hubungan positif dan signifikan antara kemampuan unpacking dan kemampuan konstruksi negasi pada calon guru matematika. Hasil penelitian ini memberikan implikasi praktis pada pembelajaran logika, khususnya pernyataan matematika. Pembelajaran logika perlu mengembangkan proses untuk mendorong melakukan evaluasi mengenai pernyataan matematika. Pemahaman mengenai negasi penting proses pembelajaran logika.
Berdasarkan hasil dan pembahasan, ada dua saran yang dapat dipertimbangkan untuk penelitian selanjutnya. Pertama, penelitian berikutnya perlu mengeksplorasi lebih lanjut faktorfaktor dibalik temuan penelitian ini dengan pendekatan penelitian yang lebih komprehensif. Misalnya, studi kualitatif melihat cara calon guru menggunakan kemampuan dan hasil unpacking dalam mengkonstruksi negasi dari pernyataan matematika. Kedua, penelitian selanjutnya perlu dilakukan dengan mempertimbangkan kerangka yang lebih komprehensif dalam mengevaluasi kemampuan konstruksi negasi calon guru matematika. Misalnya, penelitian selanjutnya perlu menganalisis cara berpikir (ways of thinking) dan cara memahami (ways of understanding) dibalik proses konstruksi negasi calon guru matematika.

\section{DAFTAR PUSTAKA}

Cohen, L., Manion, L., \& Morrison, K. (2018). Research Methods in Education. Routledge.

Dawkins, P. C. (2017). On the Importance of Set-Based Meanings for Categories and Connectives in Mathematical Logic. International Journal of Research in Undergraduate Mathematics Education, 3(3), 496-522. https://doi.org/10.1007/s40753017-0055-4

Dawkins, P. C., \& Cook, J. P. (2017). Guiding reinvention of conventional tools of mathematical logic: students' reasoning about mathematical disjunctions. Educational Studies in Mathematics, 94(3), 241-256. https://doi.org/10.1007/s10649016-9722-7

Dawkins, P. C., \& Roh, K. H. (2016). Promoting Metalinguistic and 
DOI: https://doi.org/10.24127/ajpm.v10i2.3474

Metamathematical Reasoning in Proof-Oriented Mathematics Courses: a Method and a Framework. International Journal of Research in Undergraduate Mathematics Education, 2(2), 197222.

https://doi.org/10.1007/s40753-

016-0027-0

Levenson, E., Tsamir, P., Tirosh, D., Dreyfus, T., Barkai, R., \& Tabach, M. (2012). Focusing on the Interactive Development of Secondary School Teachers' Knowledge of Mathematical Statements. Investigations in Mathematics Learning, 5(2), 4456.

https://doi.org/10.1080/24727466.2 012.11790322

Macbeth, G., Razumiejczyk, E., Crivello, M. del C., Fioramonti, M., \& Girardi, C. I. P. (2013). The Shallow Processing of Logical Negation. Psychology and Behavioral Sciences, 2(5), 196. https://doi.org/10.11648/j.pbs.2013 0205.15

Morgan, M. E. (2020). Students' Quantifications, Interpretations, and Negations of Complex Mathematical Statements from Calculus [Arizona State University].

https://www.researchgate.net/public ation/343999913_Students'_Quanti fications_Interpretations_and_Nega tions_of_Complex_Mathematical_

Statements_from_Calculus

Ngansop, J. N. (2018). Relevance of Learning Logical Analysis of Mathematical Statements. In G. Kaiser, H. Forgasz, M. Graven, A. Kuzniak, \& E. S. B. Xu (Eds.), Invited Lectures from the 13th International Congress on Mathematical Education (pp. 441462). Springer Open. https://doi.org/10.1007/978-3-31972170-5_32
Nurjanah, Wahyudin, \& Prabawanto, S. (2019). Overcoming students' difficulties in understanding the negation concepts by providing contextual-based student worksheet. AIP Conference Proceedings, 2194(1), 1-9. https://doi.org/10.1063/1.5139807

Shipman, B. A. (2016). Subtleties of hidden quantifiers in implication. Teaching Mathematics and Its Applications, 35(1), 41-49. https://doi.org/10.1093/teamat/hrv0 07

Stewart, J. (2012). Calculus: Early Transcendentals (7E ed.). Brooks/Cole.

Sugiyono. (2012). Metode Penelitian Kuantitatif, Kualitatif dan R\&D. In Alfabeta. Alfabeta.

Tabach, M., Levenson, E., Barkai, R., Tsamir, P., Tirosh, D., \& Dreyfus, T. (2012). An organizer of mathematical statements for teachers: The six-cell matrix. International Journal of Mathematical Education in Science and Technology, 43(6), 765-777. https://doi.org/10.1080/0020739X.2 012.662287

Tamba, K. P. (2020). Analisis Kesalahan pada Materi Kuantifikasi Menggunakan Matriks Enam Sel. Jumlahku: Jurnal Matematika Ilmiah, 6(2), 1-14. https://doi.org/https://doi.org/10.33 222/jumlahku.v6i2.1053

Uygur-Kabael, T. (2017). Ortaokul matematik öğretmen adaylarının informalden formal matematik diline çevirme Transfer Skills of Middle School Pre-service Mathematics Teachers from Informal to Formal Mathematical Language: Turkey and United States Cases. Hacettepe Egitim Dergisi, 32(4), 1013-1031. https://doi.org/10.16986/HUJE.201 6023349 